Denis Toiczkin • Денис Тоичкин Narodowa Akademia Nauk Ukrainy, Kijów

ORCID ID: 0000-0003-0433-8335
OBLICZA WOJNY

TOM $3 \cdot$ MIASTO I WOJNA

ŁÓDŹ $2021 \cdot$ ISBN 978-83-8220-556-5 • s. 63-80

https://doi.org/10.18778/8220-556-5.04

\title{
КЛИНКОВОЕ ОРУЖИЕ С ГОРОДСКОЙ ГЕРБОВОЙ МАРКИРОВКОЙ В КОЛЛЕКЦИИ ЛЬВОВСКОГО ИСТОРИЧЕСКОГО МУЗЕЯ
}

\begin{abstract}
Streszczenie. Artykuł dotyczy eksponatów broni białej ze zbiorów Lwowskiego Muzeum Historycznego, oznaczonych herbem miasta Lwowa. Autor bada egzemplarze broni z herbami wykonanymi w różnych formach - od zatwierdzonej w 1526 r., po „papieską”, przyjętą w 1586 r., a także odmiany lokalne. Omówiony został półtoraręczny miecz (tzw. bękart) z XVI w. i szabla ceremonialna z XVIII w. Analiza wizerunków heraldycznych obejmuje także dwuręczny miecz bojowy, dwie szable i miecze. Ogólna chronologia badanego uzbrojenia i herbów obejmuje ponad trzysta lat - od XVI do drugiej połowy XIX w. Stosując interdyscyplinarne metody badawcze, autor określił cel oraz możliwe obszary zastosowania takiego systemu znakowania. Jak każdy symbol własnościowy, herb miasta na broni określał przede wszystkim prawa własności lub wskazywał nabywcę broni. Tym samym herb miasta świadczył o tym, że broń była własnością miasta Lwowa i została zamówiona przez magistrat lub inne władze miejskie. Herb i jego elementy były używane także jako znak arsenału miejskiego lub marka majątkowa jednego z miejskich cechów. Sporadycznie występujące przypadki łączenia osobistego herbu szlacheckiego i godła miasta mogą świadczyć o przekazaniu (darowaniu) broni miastu lub o tym, że szlachcic posiadający daną broń, był członkiem administracji miejskiej. Wreszcie broń miejska i cechowa, udekorowana herbem Lwowa, miała również znaczenie ceremonialne i była wykorzystywana podczas uroczystości korporacyjnych bądź uroczystości miejskich. Autor zwraca uwagę, że na Ukrainie tradycję znakowania broni herbami miasta najpełniej reprezentuje Lwów, co świadczy o tożsamości lwowskiej kultury miejskiej, jej epokowej integracji z zachodnioeuropejskim kontekstem kulturowym i prawnym.
\end{abstract}

Słowa kluczowe: broń biała, znaki broni, herb Lwowa, broń Iwowska, Lwowskie Muzeum Historyczne 


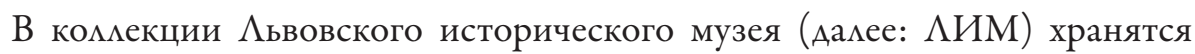
образцы уникального исторического клинкового оружия. РяА признаков, указывает на церемониальные функции (назначение) этих клинков, связывая их с обращением в среде $\Lambda$ ьвовского городского и военного нобимитета. Обращают на себя внимание кмейма с изображениями городского герба $\Lambda$ ьвова иногда в сочетании с родовыми гербами. Ао настоящего времени тема комплексного изучения оружия, маркированного гербами

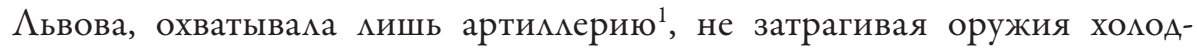
ного. Проанализируем несколько наиболее репрезентативных образцов этого оружия.

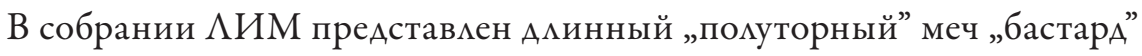
(инв. № 3-3477), явАяющийся позАней разновидностью так называемых „больших мечей” XVI в. (рис. 1).

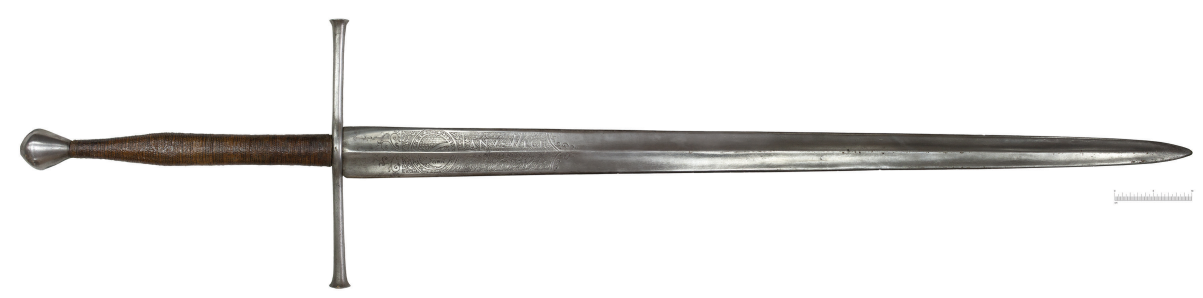

Рис. 1. Меч „бастард”, Львов (?), XVI в. (ЛИМ, инв. № 3-3477. Фот.: Д. Тоичкин)

В XX в. Изображение и описание меча несколько раз пубциковаци, в частности, в каталоге $\Lambda$ ьвовских городских музеев ${ }^{2}$, а также книге украинского искусствоведа П. Жолтовського ${ }^{3}$. Предмет был исследован нами в 2017 г. ${ }^{4} \mathrm{~B}$ процессе изучения быми установмены параметры оружия, составлена морфологическая характеристика.

${ }_{1}$ Vide: О. МАльченкО, Орнаментована артилерія на Правобережній Украйні (XV-XVIII cm.), Київ 2009.

2 Muzea gminy miasta Lwowa, Lwów 1929, s. 49, tabl. II.

${ }^{3}$ П. ЖОАтовсьКий, Художній метал. Історичний нарис, Київ 1972, s. 62.

${ }^{4}$ А. Тоїчкін, Мечі з власницькою символікою у колекиї Аьвівського історичного музею, [w:] Studia edytorskie, t. 3: Edytorstwo źródet: różne drogi - wspólny cel, red. A. PERŁAKOWSKI, Kraków 2017, s. 143-168. 
Общая Алинна - 1490 мм, Алинна клинка - 1085 мм, ширина кминка возме пяты - 66 мм. Меч имеет удминенные кимьоны (335 мм) и рукоять (330 мм), а также значитемьный вес - 3290 г.

Прямой широкий двулезвийный кАинок плавно сужается к острию. ВАоль центрацьной оси симметрии с обеих сторон тянутся выразительные ребра, оканчивающиеся вблизи острия. Сечение большей части кминка имеет форму аммаза с доликами вокруг центрацьного ребра. КАинки с таким сечением характерны дия XV в. ${ }^{5}$ Очевидно меч следует отнести к типу XVIII по кмассификации Окшотта ${ }^{6}$. Эта разновидность отлично приспособлена Аля рубки и укола. На многих мечах этого типа еще с XV в. появ яется начацьная форма рикассо, которое окончательно утверждается на клинках в XVI в. Отсутствие его на исследуемом кминке может свидетельствовать о значительно более раннем происхождении меча, по сравнению с датой, указанной на кминке (1572).

Эфес открытого типа, простая крестовина с Алинными трубчатыми кимьонами плавно расширяется к концам, завершаясь плоскими шияпками. Такой стиль исполнения (тип 10 по Окшотту) фиксируются на артефактах начиная с XV в. ${ }^{7}$ Навершие типа T3 (по Окшотту) преАстав яяет группу пробковидных наверший, функционировавших со второй половины XIV Ао конца XVI вв. ${ }^{8}$

Рукоять отреставрирована в XX в. в стиле, характерном Аля мечец̆-бастардов XVI в.

Особый интерес представцяет кцинковая симвоцика и эпиграфика, нанесенная на обеих плоскостях кцинка: с одной стороны, расположен герб Аьвова, окруженный венком и надпись 'A.D.1577'. C Аругой - герб в венке и наАпись „IANVS WEGR / ZIN M SIGIETA” (рис. 2).

Авторы каталога 1929 г. перевеми надпись как „Януш Венгр из города Сигета”. Очевидно, здесь упоминается румынский город Сигету-Мармацией (рум. Sighetu Marmației). Известный с первой половины XIV в., город более шести столетий бым столицей комитата Мармарош

5 Э. Окшотт, Меч в век рыцарства. Классификащия, типология, описание, Москва 2007, s. 73.

${ }^{6}$ Ibidem, s. 84-85.

7 Ibidem, s. 149, фото 25, 46Г.

${ }^{8}$ E. OAKeSHOTT, European Weapon and Armour from the Renaissance to the Industrial Revolution, Woodbridge 2000, s. 135. 

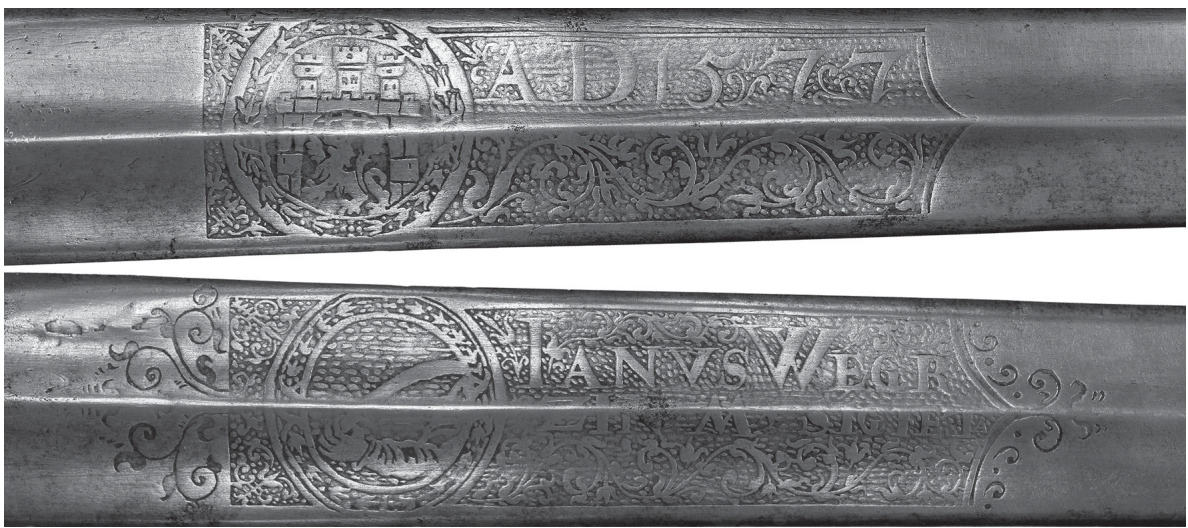

Рис. 2. Изображения и надписи на плоскостях клинка на мече (ЛИМ, инв. № 3-3477. Фот.: Д. Тоичкин)

на северо-востоке Венгерского королевства 9 . В разных вариантах написания, название города состоя о из двух частей - первая была названием комитата, вторая - города. Возможно, с этим связана заглавная Аитера „M” переА „SIGIETA”.

Герб явцяет собой помьскую разновидность хорошо известного геральдистам герба „Погоня”. Этим чрезвычайно популярным гербом в Речи Посполитой владели десятки семейств, поэтому установить собственника, основываясь только на форме центрацьной гербовой фигуры невозможно.

Правее герба размещено имя „IANVS WEGR” (Януш Венгр). Исследовав тексты и символы, составители музейного описания $\Lambda$ И, предпо-

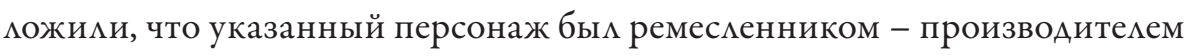
меча. Аналогичного мнения придерживался и П. Жолтовський, который

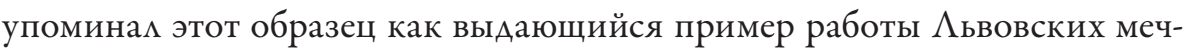
ников, а также отметиц оформление меча протравленным орнаментом в ренессансном стиле ${ }^{10}$.

9 Primăriei Municipiului Sighetu Marmației. Istoricul localităţii, http://www.primaria-sighet.ro/ pagina/istoricul-localita-ii (доступ: 19 I 2021).

${ }^{10}$ П. ЖОАтовський, ор. cit., s. 62-63. 
Отвечая на преАположения относительно возможности изготовления меча указанной на киинке персоной, отметим, что симвоц „Погоня” явмяется шияхетским гербом, а не производственным знаком. Кроме того, в XVI в. ни в Речи Посполитой, ни в Европе в целом не было принято размещать имя ремесленника и его клеймо настолько большого размера, почти полностью занимая ими симьную часть кцинка. Таким образом, на наш взгляд, на плоскости клинка нанесена владельческая символика и эпиграфика, и указанный Януш Венгр бым шияхетным собственником меча и герба. Аобавим, что имя „Януш Венгр” (Венгрин) нередко встречается в документах, где упоминаются представители польской шияхты

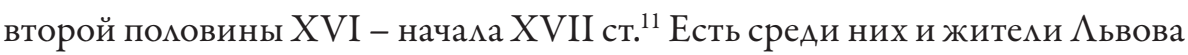
(запись за 1631)12.

На обратной стороне кминка нанесен герб Аьвова (рис. 3). В трехбашенных крепостных воротах с полуопущенной решеткой, размещен мев с поднятым хвостом, шагающий вправо. Полукруглый своА ворот обрамлен камнем, стена и башни увенчаны тремя зубцами (бланками). Стена прорезана под каменную кмадку ориs isodomum. Средняя башня выше Авух боковых, все башни имеют по три бойницы.

Официально герб Аьвова бым утвержден указом польского коромя Сигизмунда I в 1526 г. ${ }^{13}$ Именно с этого периода многочисленные изобразительные источники начинают фиксировать изменение положения мьва с „меопардового” (как на печати Аьвовского магистрата 1359 г.) на „встающего” (стандартное герацьдическое).

По мнению авторов катацога 1929 г., городской герб на кминке свидетемьствует о церемониацьном назначении меча. Исследователи $А И М$ идут дацьше, утверждая, что меч служиц символом вцасти Аавы - магистратского суда $\Lambda$ ьвова, явцяясь в то же время выносным мечом, который несли перед городским главой во время торжественных процессий. Тут следует обратить внимание, что символика Аавы (по крайней мере на

11 Vide: K. NiESIECKI, Herbarz polski Kaspra Niesieckiego powiększony dodatkami z późniejszych autorów rękopismów, dowodów, urzędowych i wydany przez Jana Nep. Bobrowicza, t. 9, Lipsk 1841, s. 262.

${ }_{12}$ Akta grodzkie i ziemskie z czasów Rzeczypospolitej Polskiej z archiwum tak zwanego bernardyńskiego we Lwowie w skutek fundacyi śp. Alexandra hr. Stadnickiego, t. 20, Lwów 1909, s. 302.

13 А. Гречимо, Герб міста Аввова: генеза, традиціл, відродження, https://lvivancient.org/ statti/herb-mista-lvova-geneza-tradytsiia-vidrodzhennia/ (Аоступ: 19 I 2021). 


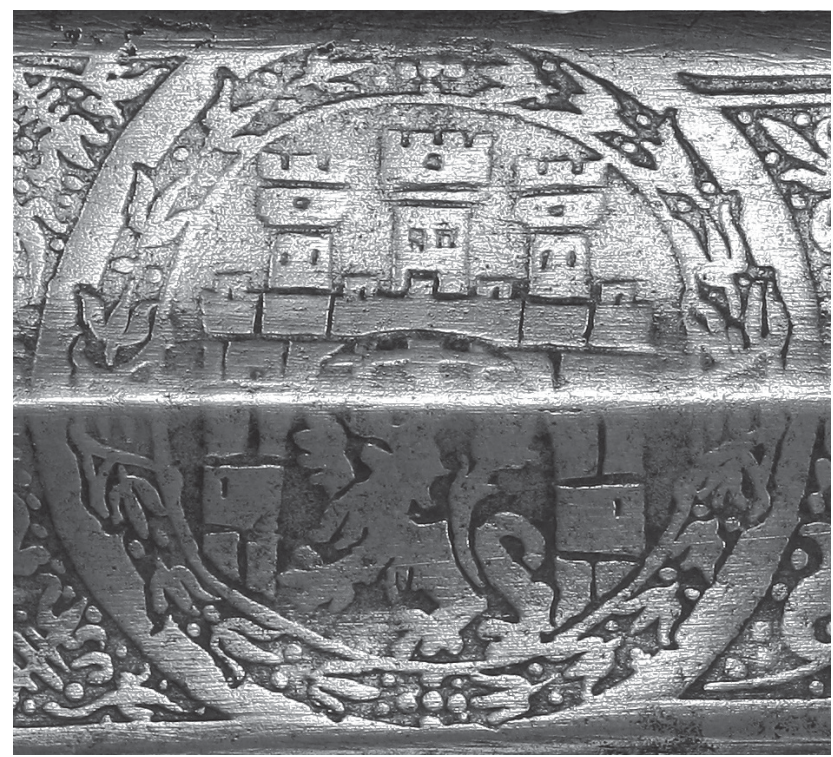

Рис. 3. Герб Львова на плоскости клинка на мече (ЛИМ, инв. № 3-3477. Фот.: Д. Тоичкин)

печатях) традиционно представцяла модификацию городского герба, в частности, количество башен было уменьшено до одной ${ }^{14}$. На мече же изображен полноценный городской герб. Тем не менее, появление герба на кАинке действительно может свидетельствовать о функционирова-

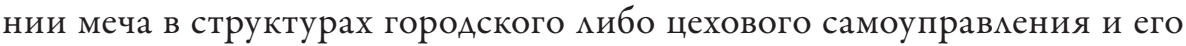
церемониальном значении. Известно, что после завоевания Аьвова Польским королевством, указанный городской символ стал необычайно популярен в городской среде: он широко использовался не только на печатях, но и на знаменах, цеховых знаках, им метими топменый воск и размичные изделия, даже украшами фасады домов ${ }^{15}$.

На возможность церемониацьного использования указывают и морфологические особенности меча. Образец явцяется представителем полутораручных бастардов - мечей большого размера с широкими Авулезвийными кминками и Алинными рукоятями, которые при необходимости можно удерживать двумя руками. По Алине они занимахи

\footnotetext{
14 Ibidem.

15 Ibidem.
} 
промежуточное положение между одноручными и двуручными мечами ${ }^{16}$. По мнению Э. Окшотта, бастарды сформировацись в процессе развития мечей более ранних типов, которые заложими в Европе традицию „больших мечей”, ими „мечей дмя войы” (Espées de Guerre, Grete Swerdes): типов XIIa и XIIIа в конце XIII - начаме XIV вв., а также типов XV и XVIII в период XV в. ${ }^{17}$ Мечи типа XVIII, к которому принадмежит рассматриваемый образец, быми наиболее популярны в Европе в период 1410-1510 гг.

Аобавим, что по морфологии и типу кминковой символики и эпиграфики меч имеет исторические аналоги. Так, меч князя Николая Радзивим а (г.ж. 1512-1584), хранящийся в Немецком историческом музее в Берлине (инв. № W2265), хоть и относится к более актуальному Аля XVI в. типу XX, но имеет схожую со Аьвовской маркировку на кминке - год (1572), герб и имя вмадемьца ${ }^{18}$.

Возможность церемониацьного использования Аьвовского меча подтверждается практикой (парадного) использования больших „выносных" мечей в Европе. Ааже в период активного функционирования их в качестве боевых, уже существовали особые парадные экземпляры, которые выносими удерживая перед собой во время торжественных шествий ${ }^{19}$. Огромные размеры отдельных мечей производили впечатление на публику, хотя и искмючами их боевое применение. Абсомютный рекорд исследователи приписывают мечам мичной охраны графа Эдуарда Честерского последней четверти XV в., Алинна которых достигала 2,26 м. ${ }^{20}$

Исследованный нами Аьвовский меч не отличается такими гигантскими размерами, хотя его целиком можно отнести к категории „больших”. Морфология свидетельствует, что он был изготовлен ранее указанной на кминке даты (1572) и не обязатемьно во Аьвове. Конструкция меча соответствует Западноевропейской оружейной традиции конца XIV - начала $\mathrm{XV}$ в. и полностью сохраняет боевую функционацьность. Скорее всего

16 The Complete Encyclopedia of Arms \& Weapons, eds. L. Tarassuk, C. Blair, New York 1982, s. 80.

17 Т. ААЙБАЕ, Меч: Большая иллюстрированная энииклопедия, Москва 2008, s. 94; Э. ОКШOTT, op. cit., s. 52-53.

${ }^{18}$ H. MÜlLER, H. KöLling, Europaische Hieb-und Stichwaffen: Aus der Sammlung des Museums fur Deutsche Geschichte, Berlin 1984, s. 198-199.

19 The Complete Encyclopedia of Arms \& Weapons, s. 473-475.

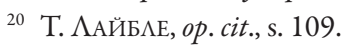


полутораметровый меч действительно использовался в церемониацьных целях в соответствии с европейской традицией больших выносных мечей, ведь к 1572 г. его конструкция уже изрядно устарела.

Сочетание вцадемьческого и городского гербов может иметь разцичное объяснение. ВАадельческий могли нанести ранее городского и гербы могут быть никак не связаны Аруг с Аругом. Возможно также, что собственник меча, Януш Венгр, занимац не последнее место в управлении городскими делами, отметив это городским гербом на мече, совместив его с собственным вцадельческим символом. На наш взгляА, вероятнее, что этот мещанин пожертвовац меч городу, торжественно зафиксировав дату подарка. Это подтверждается широко известной по другим вещественным источникам традицией нанесения больших донаторских гербов. Множественные аналогии встречаются в декоре $\Lambda$ ьвовской артим ерии, подаренной городу местной шияхтой ${ }^{21}$.

Аругой выразительно декорированный образец ( $А$ М, инв. № 3-3479, рис. 4) - сабля, относится к значительно более позднему периоду. Сабля поступима в музей в 1940-х гг. Общая Алинна - 990 мм, Алинна кминка - 845 мм, ширина кминка возме пяты - 36 мм. Более трети последней части кцинка имеет плавное (без уступчатого перехода) расширение, т.н. „Перо”. Боевой конец Авулезвийный, радикацьно скруглен к острию, расположенному на обухе. Судя по всему, когда-то конец кминка бы обломан и, затем, восстановцен уже в представленном виде. Об этом же

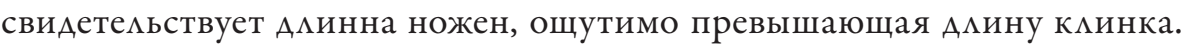

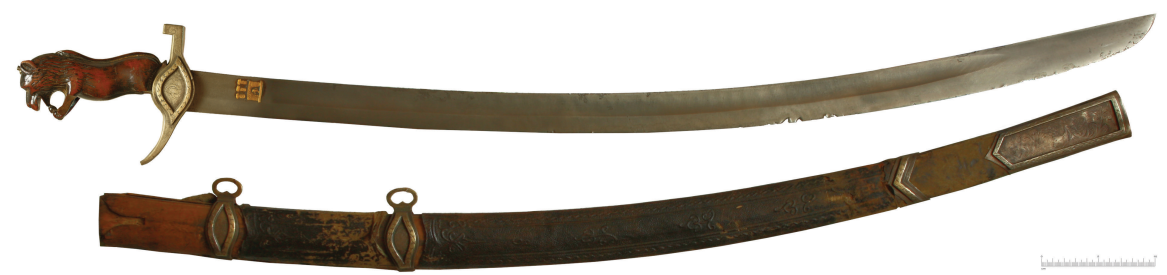

Рис. 4. Церемониальная сабля XVIII в. (ЛИМ, инв. № 3-3479. Фот.: Д. Тоичкин)

21 Персонацьная переписка с О. МАһьченкО, 2015. 
Сабля достаточно тонкая (ширина обуха 45 мм) и имеет относительно небольшой вес - 630 г (в ножнах 1020 г). С обеих сторон кминка, ближе к обуху, расположен широкий и очень глубокий дол, заканчивающийся плавным закруглением на пере. Аол занимает почти всю плоскость кминка и выполнен в стиле „Монморанси” 22 , хотя и отличается от кцассического, чуть большей глубиной и меньшей шириной. С внешней стороны

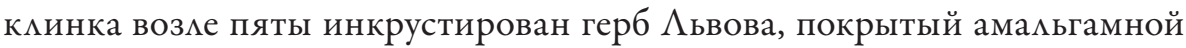
позолотой. В целом, морфология кминка характерна Аля первой половины XVIII в., но ряд черт приближает его к еще более раннему периоду.

КАинок выполнен из дамасской стали. Качество сварки пакета остав-

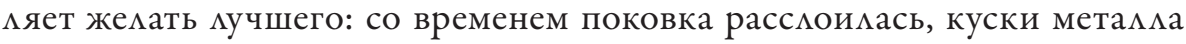
выпали. Вероятно, это произошио вследствие экстремацьной экспиуатации, о которой свидетельствуют многочисленные зарубки и крупные заломы режущей кромки, да и сам факт поломки боевого конца. Аумается, кАинок не бым предназначен Аля боевых действий - слишком

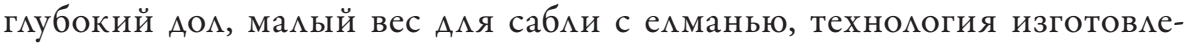
ния (пакет выведен прямо на режущую кромку). Эфес и сабельная символика, о которых скажем отдельно, также отнюдь не свидетельствуют в пользу боевого назначения кцинка.

Эфес закрытого типа (рис. 5). Гарда выполнена из низкопробного серебра ${ }^{23}$. Крестовина пустотелая, паянная, центральная часть АинзовиАной формы. Кимьоны четырехгранные в сечении, правый (передний) переходит в защитную дужку (утеряна), которая была соединена с вершиной рукояти. Аевый (задний) кицьон загнут под прямым углом вверх, образуя небомьшой выступ. По центру внешней части гарды припаяно защитное кольцо Аля пальца (палюx). Выполненное в виде широкой пластины, кольцо усимивает защиту, но значительно снижает возможности контроля сабли во время фехтования. В боевых сабцях такие широкие кольца как правимо не использовацись. Все элементы гарды покрыты гравированным растительным орнаментом. Рукоять насадная деревянная, выполнена в форме вставшего цьва, с поднятыми передними мапами в которых он удерживает стилизованные три хомма и восьмилучевую звезду наА ними - герацьдический симво $\Lambda$ ьвова.

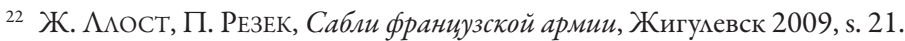

${ }^{23}$ Проба серебра ниже $800^{\circ}$. Пробирование выполнено электрохимическим прибором "Аемон-Ю”. 


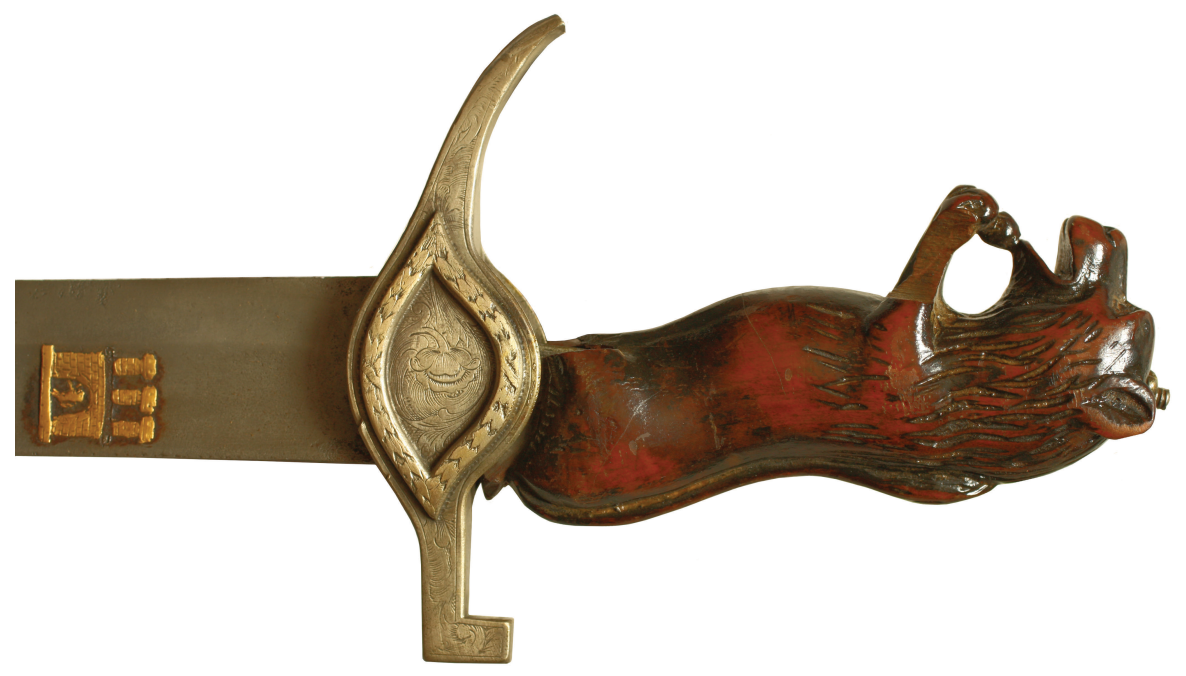

Рис. 5. Эфес церемониальной сабли XVIII в. (ЛИМ, инв. № 3-3479. Фот.: Д. Тоичкин)

Ножны деревянные, обтянутые черной кожей, на которой тиснением выполнен растительно-геометрический орнамент. Металмический прибор выполнен из белого золота и состоит из устья (утрачено), Авух Аинзовидных обоймиц с неподвижными кольцами, кольца-шеврона и массивного наконечника. Метаццические части ножен декорированы растительным орнаментом в еАином стиле с гардой.

В целом, ножны выполнены в иранском стиле, характерном Аля персидских шамширов - тут и Аве Аинзовидные обоймицы с неподвижными кольцами, и тиснение на коже. „Аинзовидный” декор даже перенесен на гарду, в центре которой изображен раскрытый бутон, окруженный напаянным миндалевидным картушем.

В то же время, сам гравированный растительный декор содержит восточноевропейские (в т.ч. украинские) и османские мотивы: подсолнухи, Аистья аканта и раскрывшиеся бутоны, выполненные в реалистичной манере на разделанном штриховкой фоне в обрамкении пунктирных контуров. Общий стиль исполнения характерен А я XVIII в.

ОтАельного внимания заслуживает „Аьвиная” символика сабли. Как уже упоминалось, на внешней стороне кцинка возме пяты расположен герб $\Lambda$ ьвова (рис. 6). Изображение представцяет „старый” городской 
герб, аналогичный ранее рассмотренному на мече, но с некоторыми отмичиями. Наиболее очевидное - все три башни имеют одинаковый размер. Такое исполнение можно встретить еще в печатных изданиях Ивана

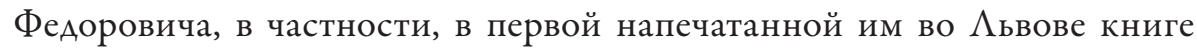
Anocmoл 1574 г.

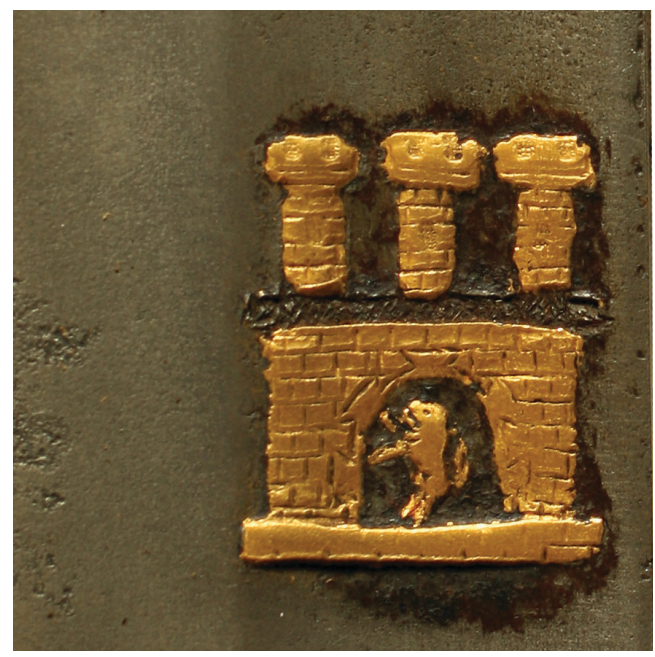

Рис. 6. Герб Львова на внешней стороне клинка церемониальной сабли XVIII в. (ЛИМ, инв. № 3-3479. Фот.: Д. Тоичкин)

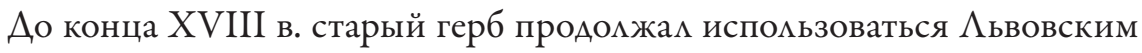
магистратом ${ }^{24}$, несмотря на то, что еще в 1586 г. город получим право на видоизмененный герб римского папы Сикста V с изображением герацьдического (вставшего) мьва, держащего в передних мапах три хомма под восьмилучевой звездой. Именно эта фигура запечатлена в форме деревянной рукояти рассмотренной сабли. Следует обратить внимание, что мев

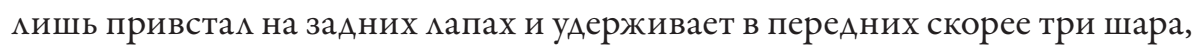
а не хомма (которые традиционно изображацись в виде усеченных эм ипсов). Такая традиция также встречается в более ранних изображениях обновленного римским папой $\Lambda$ ьвовского герба, в том числе на оружии.

В этой связи необходимо упомянуть еще один предмет -Авуручный меч, хранящийся ныне в Закарпатском краеведческом музее (рис. 7),

\footnotetext{
${ }^{24}$ А. ГРЕЧИАО, op.cit.
} 

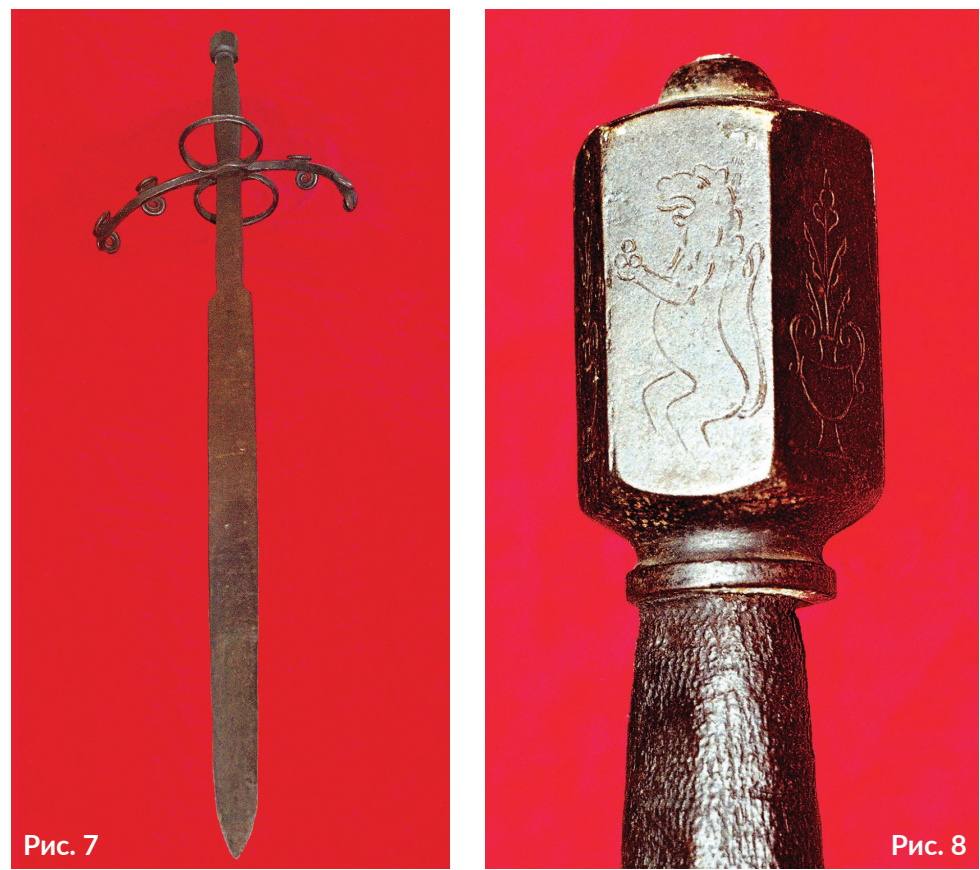

Рис. 7. Двуручный меч из коллекции Закарпатского краеведческого музея - поступил из лИМ. (Фот.: В. Гуцул, Бойові мечі з музейного зібрання Ужгородського замку, Львів 2008, s. 41)

Рис. 8. Навершие двуручного меча из коллекции Закарпатского краеведческого музея (Фот.: В. Гуцул, Бойові мечі з музейного зібрання Ужггородського замку, Львів 2008, s. 47)

поступивший туда из $\Lambda$ ИМ. Меч введен в научный оборот В. Гуцулом в книге Бойові мечі з музейного зібрання Ужгородського замкуг25. Также как исследованный нами выше бастард, двуручный меч явцяется полноценным боевым оружием XVI в., не Аишенным, однако, декоративных элементов. Оставляя в стороне проблему происхождения меча, атрибутированного автором на основе анациза кмейма как швейцарский, обратим внимание на украшение шестигранного навершия (рис. 8).

На его гранях встречается два вида гравированных изображений - центрально-симметричная растительная композиция с вазоном и кев с поднятым хвостом, привставший на задних мапах. В передних мапах у мьва - три шара. Приняв во внимание датировку предмета и тот факт,

\footnotetext{
25 В. Гуцуи, Бойові мечі з музейного зібрання Ужгородського замку, Аьвів 2008, s. 40-51.
} 


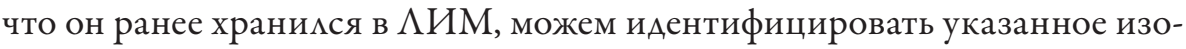
бражение, как „папский” герб города $\Lambda$ ьвова, выполненный в той же манере, что и рукоять сабли XVIII в., рассмотренная выше.

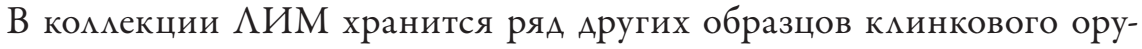
жия с изображениями на них разАичных вариантов герба $\Lambda$ ьвова. Среди них - сабля XVII в., кминок сабли XVIII в., (инв. № 3-3480), и два палаша (инв. №№ 3-1183, 3-1215) второй пом. ХІХ в. (рис. 9).

Значительное количество дошедшего до наших Аней холодного оружия с городским гербом на кминках существенно расширяет наши представцения о $А$ ьовских традициях маркировки оружия городской символикой. Ао сих пор исследователи фиксировали герб Аьвова на го-

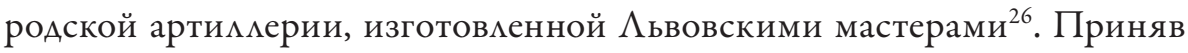
во внимание результаты изучения образцов $\Lambda$ ьовского холодного оружия отмеченного городскими гербами, а также значительное количество таких предметов в музейных комлекциях, определим круг наиболее очевидных задач, решаемых системой данной маркировки и возможные границы (области) ее применения.

Как и мюбой Аругой владельческий знак, городской герб на оружии

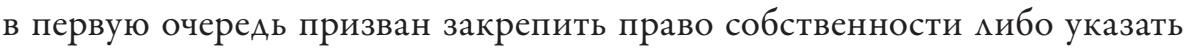
на заказчика (который как правицо и явцяется собственником) оружия. Таким образом, городской герб свидетельствовац, что вцадельцем кмейменного оружия выступаца коммунацьная община Аьвова, а реацьным распорядителем, соответственно, городской магистрат и другие органы местного самоуправцения.

Герб и его элементы могли использоваться в качестве имущественного кмейма городского арсенама, $и$ ио знака корпоративной принадмежности (ремесленные цеха нередко использовали элементы городского герба в своей символике и на презентационных изделиях $\left.{ }^{27}\right)$. Предполагаем, что упомянутый ранее двуручный меч из Закарпатского краеведческого

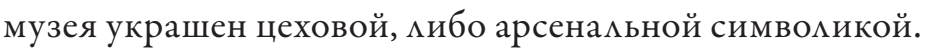

26 О. МААЬЧЕНКО, ор. cit., s. 57-58, 64, рис. 8.

27 І. СИтий, Щоденник Євгенії Спаської як джерело з історії цехових прапорів Аівобережної України, [w:] Ніжинська старовина: Збірникрегіональної історї та пам'яткознавства, Вип. 11 (14), Київ 2011, s. 61; М. КАПРААь, Якою ж була майстеритука львівських мечників?, [w:] Арогобицький краєзнавчий збірник, Вип. 10, Арогобич 2006, s. 574. 

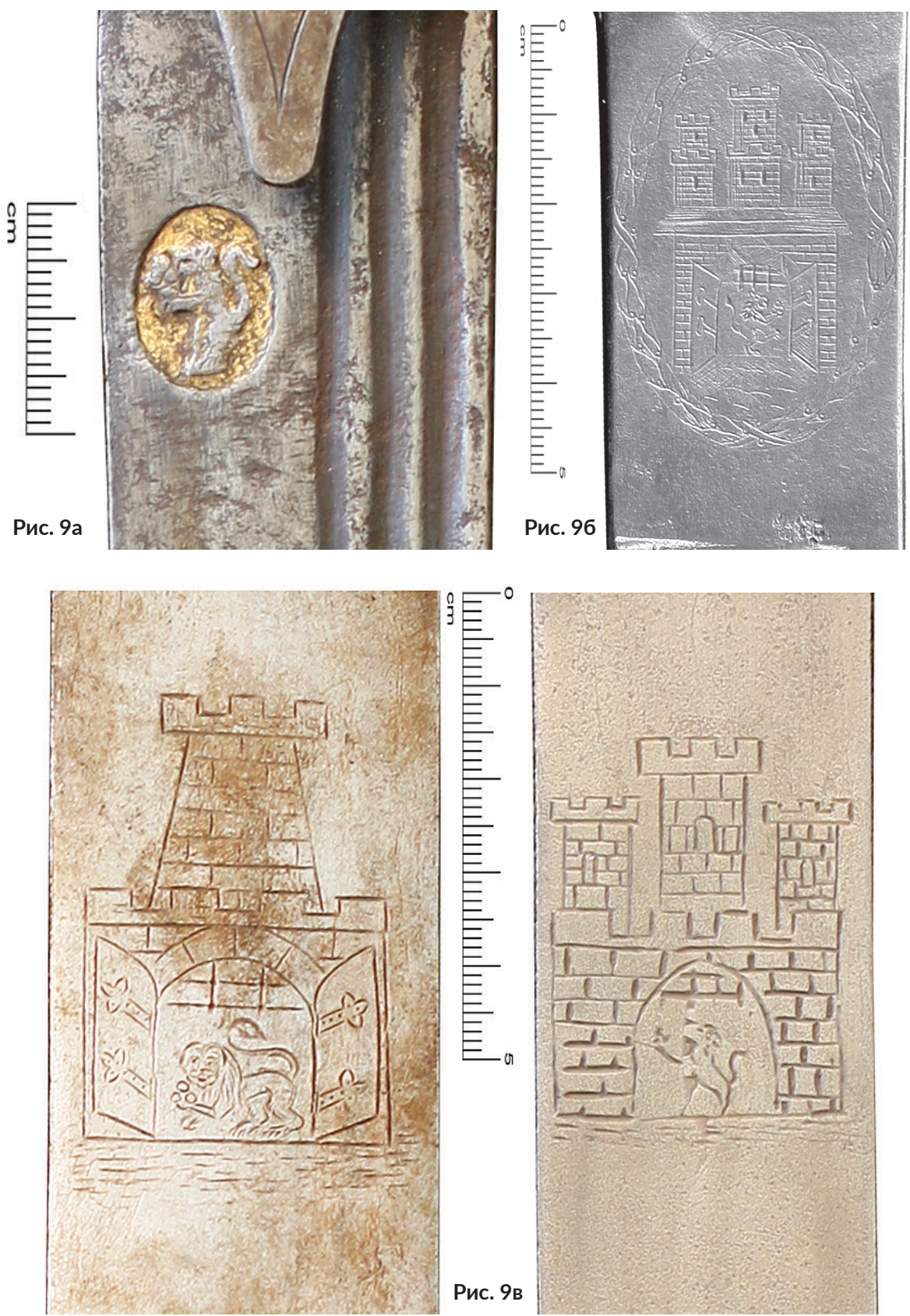

Рис. 9. Гербы Львова на клинковом оружии из коллекции ЛИМ: а - на клинке сабле XVII в.; 6 - на клинке сабли XVIII в., инв. № 3-3480; в - на палашах второй пол. XIX в., инв. №№ 3-1183, 3-1215 (Фот.: Д. Тоичкин) 
Судя по исследованному ранее полутораручному мечу, представляющему реАкое сочетание городской и собственнической символики ( $\Lambda$ ИМ, инв. № 3-3477), городским гербом могло маркироваться оружие переданное городу мибо образцы, принадлежавшие членам городского самоуправления.

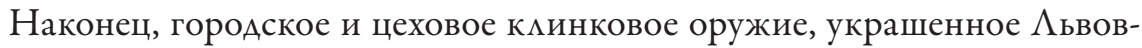
ским гербом, могло иметь церемониацьное значение. Об этом свидетельствует рассмотренная выше сабця ( $\Lambda$ ИМ, инв. № 3-3479), выполненная в нарочито „старом” стиле т.н. гусарских сабель XVII в. и имеющая явно церемониацьное назначение - она могла испоцьзоваться во время городских мибо цеховых торжественных собраний.

Мы рассмотрели Аишь насколько известных образцов оружия, марки-

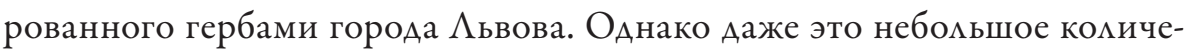
ство представцяет оригинацьную традицию, существовавшую во Аьвове более трех столетий (XVI-XIX вв.) и имеющую явно европейские корни. Особо отметим, что на территории Украины такая система маркировки наиболее полно представлена именно во $\Lambda$ ьвове, свидетельствуя о самобытности $\Lambda$ ьвовской городской культуры, ее многовековой вкАюченности в западноевропейский культурно-правовой контекст.

\section{BIBLIOGRAFIA}

\section{Źródła drukowane}

Akta grodzkie i ziemskie z czasów Rzeczypospolitej Polskiej z archiwum tak zwanego bernardyńskiego we Lwowie w skutek fundacyi śp. Alexandra hr. Stadnickiego, t. 20, Lwów 1909.

\section{Opracowania}

The Complete Encyclopedia of Arms \& Weapons, eds L. Tarassuk, C. Blair, New York 1982. Müller H., Kölling H., Europaische Hieb-und Stichwaffen: Aus der Sammlung des Museums fur Deutsche Geschichte, Berlin 1984. 
Muzea gminy miasta Lwowa, Lwów 1929.

Niesiecki K., Herbarz polski Kaspra Niesieckiego powiększony dodatkami z późniejszych autorów rękopismów, dowodów, urzędowych i wydany przez Jana Nep. Bobrowicza, t. 9, Lipsk 1841.

Oakeshott E., European Weapon and Armour from the Renaissance to the Industrial Revolution, Woodbridge 2000.

Гуцул В., Бойові мечі з музейного зібрання Ужгородського замку, $ь$ ьвів 2008 (Hutsul V., Boyovi mechi z muzeynoho Zibrannyauzhhorods'koho zamku, L'viv 2008).

Жолтовський П., Художній метал. Історичний нарис, Київ 1972 (Zholtovs'kyy P., Khudozhniy metal. Istorychnyy narys, Kyyiv 1972).

Капрахь М., Якою ж була майстерштука львівських мечників? [w:] Арогобицький краєзнавчий збірник, Вип. 10, Арогобич 2006, s. 571-574 (Kapral' М., Yakoyu zh bula maystershtuka l'vivs'kykhmechnykiv? [w:] Drohobyts'kyy krayeznavchyyzbirnyk, Vyp. 10, Drohobych 2006, s. 571-574).

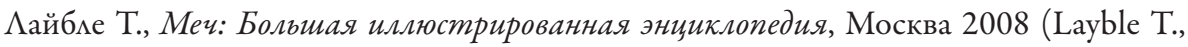
Mech: Bol shaya illyustrirovannaya entsiklopediya, Moskva 2008).

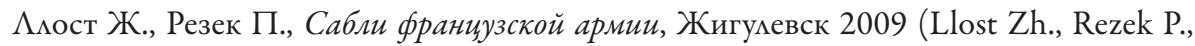
Sabli frantsuzskoy armii, Zhigulevsk 2009).

Мальченко О., Орнаментована артилерія на Правобережній Україні (XV-XVIII cm.), Київ 2009 (Mal'chenko O., Ornamentovana artyleriya na Pravoberezhniy Ukrayini (XV-XVIII st.), Kyyiv 2009).

Окшотт Э., Меч в векрыцарства. Классификация, типология, описание, Москва 2007 (Okshott E., Mech v vek rytsarstva. Klassifikatsiya, tipologiya, opisaniye, Moskva 2007).

Ситий І., Щоденник Євгенії Спаської як джерело з історії иехових прапорів Аівобережної України, [w:] Ніжинська старовина: Збірникрегіональної історї̈ та пам'яткознавства, Вип. 11 (14), Київ 2011, s. 57-68 (Sytyy I., Shchodennyk Yevheniyi Spas'koyi yak dzherelo z istoriyi tsekhovykh Praporivlivoberezhnoyi Ukrayiny, [w:] Nizhyns'ka starovyna: Zbirnyk rehional noyi istoriyi ta pam"yatkoznavstva, Vyp. 11 (14), Kyyiv 2011, s. 57-68).

Тоїкін А., Мечі з власницькою символікою у колекціӥ Аввівського історичного музею, [w:] Studia edytorskie, t. 3: Edytorstwo źródet: różne drogi - wspólny cel, red. A. Perłakowski, Kraków 2017, s. 143-168 (Toyichkin D., Mechi z vlasnyts'koyu symvolikoyuu kolektsiyi L'vivs'koho istorychnoho muzeyu, [w:] Studia edytorskie, t. 3: Edytorstwo źródet: różne drogi - wspólny cel, red. A. Perłakowski, Kraków 2017, s. 143-168). 


\section{Netografia}

Primăriei Municipiului Sighetu Marmației. Istoricul localității, http://www.primariasighet.ro/pagina/istoricul-localita-ii (Аоступ: 19 I 2021).

Гречимо А., Герб міста Аввова: генеза, традичія, відродження, https://vivancient.org/ statti/herb-mista-lvova-geneza-tradytsiia-vidrodzhennia/ (Аоступ: 19 I 2021).

\section{Denis Toichkin}

\section{BLADED WEAPON MARKED WITH THE CITY COAT OF ARMS IN THE COLLECTION OF THE LVIV HISTORICAL MUSEUM}

Summary. The article examines the exhibits of cold bladed weapons from the Lviv Historical Museum, marked by the city emblem of Lviv. The author studies samples with coats of arms made in different traditions - from the form approved in 1526 to the "papal", adopted in 1586 and the local variations as well. The Bastard sword of the 16th century and the ceremonial saber of the $18^{\text {th }}$ century studied thoroughly. The analysis of heraldic images also includes a two-handed battle sword, two sabers and swords. The general chronology of the studied weapons and coats of arms covers more than three hundred years - from 16 to the second half of $19^{\text {th }}$ century. Applying interdisciplinary research methods, the author identified the range of tasks of such a mark system and the possible areas of its application. Like any other ownership symbol, the city's coat of arms on weapons had to establish property rights or indicate the customer of weapons, first. Thus, the city coat of arms testified that the weapon was in the communal property of Lviv, and it was ordered by the magistrate and other local governments. The coat of arms and its elements were used as a mark of the city arsenal or property brand of one of the city guilds. The rare cases of combining the personal noble coat of arms and the city emblem may indicate the transfer (donation) of weapons to the city or the fact that a noble owner of weapon was a member of the city administration. Finally, the city and guild weapons, decorated with the Lviv coat of arms, had a ceremonial significance, being used during corporate and city celebrations. The author notes that in Ukraine, the tradition of marking weapons with the city emblems is most fully represented in Lviv, testifying to the identity of Lviv urban culture, its age integration into the Western European cultural and legal context.

Keywords: bladed weapon, weapon marks, coat of arms of Lviv, Lviv weapon, Lviv Historical Museum 
